FACTA UNIVERSITATIS

Series: Physical Education and Sport, Vol. 18, No 2, 2020, pp. 431 - 438

https://doi.org/10.22190/FUPES180831040D

Research article

\title{
PERCEPTION OF COHESION IN INTERACTIVE SPORTS TEAMS
}

UDC 796.035:316.7

\author{
Gordana Dobrijević1, Jelena Đorđević Boljanović1, \\ Slavko Alčaković1, Snežana Lazarević \\ ${ }^{1}$ Faculty of Physical Culture and Sports Management, Singidunum University, \\ Belgrade, Serbia \\ ${ }^{2}$ College of Sports and Health, Belgrade, Serbia
}

\begin{abstract}
The aim of this study is to examine the perception of cohesion in highly interdependent sports teams, compare cohesion in different sports, and then compare social and task cohesion. The participants were 205 professional sports players in the city of Belgrade, Serbia. They are engaged in five different sports: Football/soccer, basketball, volleyball, handball, and water polo. The Group Environment Questionnaire (GEQ) was used to collect the data. All the analyses were carried out with the SPSS 22 statistical software. The results have shown moderately-high levels of all four aspects of cohesion (Group Integration-Task, Group Integration-Social, Individual Attractions to the Group-Task, and Individual Attractions to the Group-Social) in all sports. Overall, perception of task cohesion is higher than perception of social cohesion. The study also reveals that the type of sport played impacts the level of cohesion, with basketball players having the highest scores of all.
\end{abstract}

Key words: Sports Teams, Interactive Sports, Cohesion, Group Environment Questionnaire

\section{INTRODUCTION}

Over the past decades, cohesion has been one of the most studied group characteristics (Widmeyer \& Williams, 1991; Carron, Colman, Wheeler, \& Stevens, 2002; Sabin \& Marcel, 2014). In sport studies, the most widely used definition of cohesion is that of Carron, Brawley, and Widmeyer (1998): Group cohesion is "a dynamic process reflected in the tendency for a group to stick together and remain united in the pursuit of its instrumental objectives and/or for the satisfaction of member affective needs" (p. 213). Cohesion is one of the four most important motivational mechanisms in a team, together

Received August 31, 2020 / Accepted September 10, 2020

Corresponding author: Gordana Dobrijević

Faculty of Physical Culture and Sports Management, Singidunum University, Danijelova 32, 11000 Belgrade, Serbia

Phone: + 381113094094 • E-mail: gdobrijevic@ singidunum.ac.rs 
with collective mood or group emotion, collective efficacy, and conflict. Team cohesion is especially important for teams which rely on the communication and coordination of its members, and whose members depend on each other (Bell \& Brown, 2015). It leads to increased satisfaction (Widmeyer \& Williams, 1991), decreased pre-competition anxiety (Eys, Hardy, Carron, \& Beauchamp, 2003), higher perceived performance, viability, and satisfaction (Tekleab, Quigley, \& Tesluk 2009), as well as higher perceived self-efficacy (Marcos, Miguel, Oliva, \& Calvo, 2010). Cohesion also promotes group affiliation and network support in a team (Hassell, Sabiston, \& Bloom, 2010).

Cohesion can emerge from two distinct groups of factors: social cohesion (based on social bonds and relationships between the team members) and task cohesion (based on the joint responsibility of accomplishing the team's tasks). Additionally, it develops on two levels: the personal (perception of individual attraction to the group), and group (perception about the group as an entity). With these subgroups of cohesion in mind, Carron, Widmeyer, and Brawley (1985) created the Group Environment Questionnaire (GEQ), today commonly used to determine perceptions of cohesion amongst adults. Carron (1982) claims that, in sports settings, task cohesion (to what degree the players are committed to and focus on a common task) affects performance more strongly than social cohesion (a degree to which members of a team like the other players, and how much pleasure and pride they take in the group). A meta-analysis of 17 studies by Filho, Dobersek, Gershgoren, Becker, and Tenenbaum (2014) showed a stronger link between task cohesion and performance than between social cohesion and performance. Moreover, Dunlop, Falk, and Beauchamp (2012) discovered that perception of task cohesion remains relatively stable across several exercise sessions, while perception of social cohesion varies over time. The research by Haddera (2015) also suggests that task cohesion is especially important in increasing team performance in sports teams.

Some authors claim there is a connection between interdependence and cohesion in sports (Cockerill, 2002; Cotterill, 2012; Murray, 2006). Murray's (2006) research underlined the importance of interdependence in team sports, and consequently the need for cohesion. The author found that even the smallest changes in interdependence can influence the need for team cohesion, and consequently can impact team performance. According to Cotterill (2012), sports that need more cooperation will also need a higher level of cohesion. The more players need others for success, the higher the level of task cohesion will be. In other words, cohesion helps performance in all sports, but much more so in sports where there is a high need for coordination and cooperation. In this paper we chose sports with high team interdependence (basketball, volleyball, football/soccer, handball, and water polo) to examine their levels of cohesion. In these sports, players' interaction is crucial for the team's performance, much more than their individual actions.

Fry, Kerr, and Lee (1986) contrasted highly interdependent sports, such as football, basketball, ice hockey, and volleyball, and low interdependence sports, such as golf, tennis, wrestling, swimming, and track. Keidel (1984) differentiated between pooled interdependence (each member acts relatively independently, with sporadic interaction with other members, like in baseball); sequential interdependence, where members interact in series, like in football teams (American football), and reciprocal interdependence, where every member interacts with all other members, like in basketball teams. Whereas in American football or cricket every player is assigned his/her own role, in basketball every player must be able to play offense, defense, and transition (Keidel, 2014). Feltz, Short, and Sullivan (2007) also found that different sports require different levels of interdependence, from golf (low), baseball, and American football (moderate) to basketball and soccer/football (high). Andersen (2005) emphasized basketball, water polo, and volleyball as interactive sports. 
Based on Keidel's classification, Pescosolido and Saavedra (2012) examined the value of group cohesion for different sports, from basketball as one of the most complex (with team or reciprocal interdependence) to baseball as one of the least complex (pooled interdependence). For these authors, cohesion is a common social field, where the aim of increasing team performance comes through learning about each other. In this sense, not all teams benefit from higher social cohesion. It will be only the teams who make real-time decisions during games, where players participate in strategy creation together with their coach, with high coordination requirements.

In a meta-analysis spanning over ten years and comprising 17 studies on cohesion and performance, Filho and associates (2014) found their stronger positive correlation for players in coactive sports than in interactive sports. Regarding sport types, these studies focused either on coactive or interactive sports in general. However, to the authors' best knowledge, apart from Brisimis, Bebetsos, and Krommidas (2018), who found significant differences in group cohesion between sports, there were no studies comparing cohesion levels in different interactive sports.

The aim of this paper is twofold: first, to examine the level of cohesion in highly interdependent sports teams, and then compare social and task cohesion.

\section{METHOD}

\section{Participants}

In this research, non-probability-purposive sampling was used. The participants were 205 professional sports players in the city of Belgrade, Serbia. They are engaged in five different sports: football/soccer $(\mathrm{N}=25)$, basketball $(\mathrm{N}=67)$, volleyball $(\mathrm{N}=28)$, handball $(\mathrm{N}=51)$, and water polo $(\mathrm{N}=34)$, with respective percentage $12.2 \%, 32.7 \%, 13.7 \%, 24.9 \%$, and $16.6 \%$. Regarding their age, the participants were classified into the following groups: $18-25$ years $(51.7 \%), 26-30$ years $(43.9 \%)$, and over 30 years $(4.4 \%) ; 66.3 \%$ were male, and $33.7 \%$ were female.

\section{Design and procedure}

The members of each team completed the questionnaire before training. All procedures took place at the sporting grounds of each team. Each athlete read and completed the questionnaire on their own. The data were collected from September 2017 to March 2018. All the analyses were carried out with the SPSS 22 statistical software.

\section{Instrument}

The data were collected via the Group Environment Questionnaire (GEQ). This questionnaire, created by Carron et al. (1985), is widely used to determine adult perceptions of cohesion. It splits cohesion into two subgroups: group integration and individual attractions to the group. They are later subdivided into task and social matters, making up four final dimensions. They are a) Group Integration-Task (GI Task) - the group's integration based on mutual goals; b) Group Integration-Social (GI Social) - the group's integration based on social interaction; c) Individual Attractions to the Group-Task (ATG Task) - attraction of individual members to the group's goals; and d) Individual Attractions to the Group-Social (ATG Social) - attraction of individual members to the group as a unit. This questionnaire is extensively used in sport psychology and has been found to be both reliable and valid in various respects (Widmeyer, Brawley, \& Carron (1985); Brawley, Carron, \& Widmeyer, 1987). 
A previous study of Carless and De Paola (2000) was based on a modified GEQ, reduced to ten items to assess global cohesion. The GEQ has so far shown good psychometric characteristics in several different languages. For example, Iturbide, Elosua, and Yanes (2010) successfully used GEQ in Spanish sport settings. Several years later, Pulido, García-Calvo, Leo, González-Ponce, \& Sánchez-Oliva (2015) used a shorter version of the GEQ, again in Spanish. Their research proved this version of the GEQ with twelve items to be valid and reliable. The questionnaire was also validated in Brazil for use in Portuguese by Nascimento Junior, Vieira, Rosado, \& Serpa (2012), and in Czech by Prokešová, Musálek, and Chalupová (2012). Ohlert, Kleinknecht, \& Kleinert (2015) adapted the GEQ for use in German speaking countries, while Sindik and Nazor (2011), and Sindik and Vukosav (2011) validated the Croatian version of the questionnaire.

To the best of the authors' knowledge, the GEQ was not used to measure cohesion in Serbian sports teams or any other teams for that matter. The original version of this questionnaire was translated into Serbian by a researcher with degrees in both English language and Management. Based on recommendations from two researchers from the field of psychology, instead of a 9-point Likert scale, a 5-point Likert scale was used, as is usually done in Serbia. Namely, people in that country are used to a five-point grading scale throughout elementary and secondary education, where 5 is always excellent, 2 is the lowest passing grade, and 1 means fail. Accordingly, in our questionnaire 5 signifies "I strongly agree," and 1 "I strongly disagree."

In this study, the four cohesion dimensions all proved internally consistent within the present sample, with Cronbach's (1951) alphas IATG-S, IATG-T, GI-S and GI-T exceeding Nunnally's (1970) criteria of 0.70 (Table 1).

Table 1 Reliability statistics for the instruments: IATG-S, IATG-T, GI-S, GI-T

\begin{tabular}{lcc}
\hline Reliability statistics & Cronbach's Alpha & $\mathrm{N}$ of Items \\
\hline IATG-S & 0.87 & 5 \\
IATG-T & 0.82 & 4 \\
GI-S & 0.89 & 4 \\
GI-T & 0.91 & 5 \\
\hline ote GI-S = Group Integration Social. GI-T = Group Integration Task
\end{tabular}

IATG-S = Individual Attraction to Group-Social. IATG-T = Individual Attraction to Group-Task3.

\section{RESULTS}

Table 2 shows the descriptive statistics for four dimensions of cohesion. The data show moderately high levels of all dimensions of cohesion (higher than 4.0).

Table 2 Summary statistics for dimensions of team cohesion

\begin{tabular}{lccrc}
\hline Variable & Mean & SD & Skewness & \multicolumn{1}{c}{ Kurtosis } \\
\hline IATG-S & 4.2107 & 0.60947 & -0.403 & -0.724 \\
IATG-T & 4.3878 & 0.5259 & -0.503 & -0.633 \\
GI-S & 4.028 & 0.61497 & -0.005 & -0.922 \\
GI-T & 4.0468 & 0.70025 & -0.323 & -0.816 \\
\hline
\end{tabular}

Note: GI-S = Group Integration Social. GI-T = Group Integration Task. IATG-S = Individual Attraction to Group-Social. IATG-T = Individual Attraction to Group-Task. SD - Standard deviation 
After obtaining the results, the authors conducted a one-way ANOVA, which compares the means of four dimensions of cohesion (IATG-S, IATG-T, GI-S, GI-T - dependent variables) in different sports (independent variable) in order to determine whether they are statistically significantly different from one another. The one-way ANOVA demonstrated significant variations between different sports for all of the cohesion dimensions scores on GI-S, F (4, 200)=4.86, p.<.05; for GI-T, F $(4,200)=4.59$, p<.05; IATG-S, F (4, 200)=4.39, $\mathrm{p}<.05$; and IATG-T, F $(4,200)=5.79, \mathrm{p}<.001$.

To further understand the data from the ANOVA, the post hoc Duncan test was conducted. The data in Table 3 show different means for different sports for each of the dimensions of cohesion.

Table 3 Levels of cohesion dimensions in different sports (Volleyball, Water polo, Football, Basketball, Handball)

\begin{tabular}{|c|c|c|c|c|c|c|}
\hline & $\begin{array}{c}\text { Volleyball } \\
\mathrm{M} \pm \mathrm{SD}\end{array}$ & $\begin{array}{c}\text { Water polo } \\
M \pm S D\end{array}$ & $\begin{array}{l}\text { Football } \\
\mathrm{M} \pm \mathrm{SD}\end{array}$ & $\begin{array}{c}\text { Basketball } \\
\mathrm{M} \pm \mathrm{SD}\end{array}$ & $\begin{array}{c}\text { Handball } \\
\mathrm{M} \pm \mathrm{SD}\end{array}$ & $\begin{array}{c}\text { Total } \\
\mathrm{M} \pm \mathrm{SD}\end{array}$ \\
\hline$\overline{\text { IATG-S }}$ & $4.26 \pm .72^{\mathrm{bc}}$ & $3.95 \pm .66^{\mathrm{a}}$ & $4.18 \pm .49^{\mathrm{abc}}$ & $4.42 \pm .52^{\mathrm{c}}$ & $4.09 \pm .60^{\mathrm{ab}}$ & $4.21 \pm .61$ \\
\hline IATG-T & $4.37 \pm .60^{\mathrm{a}}$ & $4.12 \pm .54^{\mathrm{a}}$ & $4.29 \pm .50^{\mathrm{a}}$ & $4.6 \pm .44^{b}$ & $4.35 \pm .50^{\mathrm{a}}$ & $4.39 \pm .53$ \\
\hline GI-S & $4.21 \pm .66^{\mathrm{b}}$ & $3.83 \pm .53^{\mathrm{a}}$ & $3.78 \pm .45^{\mathrm{a}}$ & $4.22 \pm .68^{b}$ & $3.93 \pm .53^{\mathrm{a}}$ & $4.03 \pm .61$ \\
\hline GI-T & $4.21 \pm .71^{\mathrm{b}}$ & $3.68 \pm .52^{\mathrm{a}}$ & $4.16 \pm .51^{b}$ & $4.21 \pm .69^{b}$ & $3.93 \pm .79^{\mathrm{ab}}$ & $4.05 \pm .70$ \\
\hline
\end{tabular}

In all cases, higher scores indicate perceptions of higher cohesiveness.

A paired-samples t-test was conducted to compare levels of social and task cohesion. There were significant variations in the scores of social cohesion $(\mathrm{M}=4.12, \mathrm{SD}=.53)$ and task cohesion $(\mathrm{M}=4.22, \mathrm{SD}=.53) ; \mathrm{t}(204)=-2.76, \mathrm{p}=0.006$.

The IATG-S mean scores in table 3 show that the level of this dimension of cohesion is highest in basketball teams and lowest in water polo teams. The results of the post-hoc Duncan test indicate that there are significant differences in the mean scores of IATG-S between water polo and two other sports (volleyball and basketball), while basketball is significantly different from handball.

The IATG-T mean scores in table 3 show that this cohesion dimension is highest in basketball teams and lowest in water polo teams. The Duncan test also shows significantly different mean scores between basketball teams and all others.

The GI-S mean scores in table 3 also show significant differences between sports. This dimension of cohesion is highest in basketball teams and lowest in football teams. Again, the data from the post hoc Duncan test indicate that there are significant differences in the mean scores of GI-S between sports.

The GI-T mean scores in table 3 show that this dimension of cohesion is highest in basketball teams and lowest in water polo teams. The results of the post hoc Duncan test demonstrate that this dimension is different between water polo teams on the one hand, and volleyball, football, and basketball teams on the other. 


\section{DISCUSSION}

The aim of this study was to measure the level of cohesion in highly interdependent sports teams, and then to compare social and task cohesion.

The findings demonstrate that athletes playing in highly interactive sports teams have high levels of perception of group cohesion. Our results show moderately-high levels of all dimensions of cohesion (higher than 4.0). This is in accordance with the study of Brisimis et al. (2018), which revealed high levels of all four cohesion dimensions in the same sports as in our study. We also confirm the findings of Cotterill (2012), who claims that sports that need more cooperation will also need a higher level of cohesion. It can be concluded that players of highly interdependent sports will have high levels of cohesions.

The results of our study demonstrate higher perceived levels of task cohesion than social cohesion. This means that team players are more united towards achieving their mutual goal, instead of developing good relationships for social purposes. This supports previous findings by Carron (1982); Mullen \& Copper (1994); Gledhill (2007); Prokešová et al. (2012); and Filho et al. (2014). Our results have led us to conclude that task commitment is the main element of group cohesion in sports teams.

Our findings also show differences in the overall levels of cohesion in different interdependent team sports. The one-way ANOVA has shown that the levels of all four dimensions of cohesion are significantly related to the type of sport played. The data have also shown that level of cohesion in all dimensions is highest in basketball teams (followed by volleyball) and lowest in most cases in water polo. This is in accordance with the study of Brisimis et al. (2018), which revealed significant differences in group cohesion depending on the type of team sport. The authors examined the same sports, namely football, handball, basketball, volleyball, and water polo, using the GAQ questionnaire. Their study showed a significant effect of team sport on ATG-S and GI-S, and a nonsignificant effect on ATG-T and GI-T. Similar to our study, they also showed that gender had no effect on cohesion. This differs from the research of Carron et al. (2002) which showed higher cohesion in female than in male teams. However, in this study the scores among team sports were distributed differently (volleyball players scored highest in AGT-S, and handball players scored lowest in GI-S).

Our results were more consistent, namely basketball players had highest scores in all cases, and water polo players lowest scores in three dimensions (and the second lowest in GI-S). High levels of perceived cohesion in basketball teams are in accord with the study of Pescosolido and Saavedra (2012), who argue that basketball, being one of the most complex sports (with high reciprocal interdependence), requires highest levels of cohesion. A potential explanation of the low score of water polo players could be that a significant proportion of effort is spent on maintaining buoyancy. Unlike other sports, water slows down movement, and there are also a lot of fouls and time wasting during the phases of transition (Hraste, Bebić, \& Rudić, 2013). It is physically a very challenging sport, and many times players just have to "wrestle" with their opponent on their own. We have already mentioned Murray's (2006) research, who found that team cohesion is impacted even by the smallest changes in players' interdependence. 


\section{CONCLUSIONS}

This paper has investigated perception of cohesion in various interactive sports teams (basketball, handball, volleyball, football, and water polo). Our findings show a moderately high perception of cohesion in all sports, especially task cohesion. The results have demonstrated that team cohesion is affected by the type of sport played, with basketball players showing the highest levels of all cohesion dimensions. The interaction and cooperation between basketball players is more important than just the sum of their individual actions. Cohesion is particularly critical because it creates team unity, necessary for good performance.

The limitation of our study is the geographical spread of participants. In some future research, it would be interesting to include other types of sports (with various levels of interdependence) and directly compare the dimensions of team cohesion. There could also be a wider, regional study that would include athletes from several countries from the Balkans.

Having in mind that cohesion affects team performance, the findings could have practical implications for sports teams and their coaches, in terms of understanding and enhancing cohesion in order to improve team efficiency. In interactive sports, cohesion promotes communication and teamwork, which are ultimately important for team performance. In sports teams, it is the force that keeps the team together.

\section{REFERENCES}

Andersen, M.B. (2005). Sport psychology in practice, (p. 47). Champaign IL: Human Kinetics.

Bell, S.T., \& Brown, S.G. (2015). Selecting and composing cohesive teams. In E. Salas, V.B. Vessey, \& A.X. Estrada (Eds.). Team cohesion: Advances in psychological theory, methods and practice. Bingley, UK: Emerald Group Publishing Limited.

Brawley, L.R., Carron, A.V., \& Widmeyer, W.N. (1987). Assessing the cohesion of teams: Validity of the Group Environment Questionnaire. Journal of Sport Psychology, 9, 275-294.

Brisimis, E., Bebetsos, E., \& Krommidas, C. (2018). Does group cohesion predict team sport athletes' satisfaction? Hellenic Journal of Psychology, 15, 108-124.

Carless, S.A., \& De Paola, C. (2000). The measurement of cohesion in work teams. Small Group Research, 31, 71-88.

Carron, A. (1982) Cohesiveness in sport groups: Interpretations and considerations. Journal of Sport Psychology, 4(2), 123-138.

Carron, A.V., Brawley, L.R., \& Widmeyer, W.N. (1998). Measurement of cohesion in sport and exercise. In: J.L. Duda (Ed.), Advances in sport and exercise psychology measurement, (pp. 213-226). Morgantown, WV: Fitness Information Technology.

Carron, A.V., Widmeyer, W.N., \& Brawley, L.R. (1985). The development of an instrument to assess cohesion in sport teams: The Group Environment Questionnaire. Journal of Sport Psychology, 7, 244-266.

Carron, A.V., Colman, M.M., Wheeler, J., \& Stevens, D. (2002). Cohesion and performance in sport: A meta-analysis. Journal of Sport \& Exercise Psychology, 24, 168-188.

Cockerill, I. (2002). Solutions in sports psychology. Boston MA: Cengage Learning EMEA.

Cotterill, S. (2012). Team psychology in sports: Theory and practice. New York NY: Routledge.

Cronbach, L.J. (1951). Coefficient alpha and the internal structure of tests. Psychometrika, 16, 297-334.

Nunnally, J.C. (1978). Psychometric theory (2nd Ed.). New York: McGraw-Hill.

Dunlop, W.L., Falk, C.F., \& Beauchamp, M.R. (2012). How dynamic are exercise group dynamics? Examining changes in cohesion within class-based exercise programs. Health Psychology, 32, 1240-1243.

Eys, M.A., Hardy, J., Carron, A.V., \& Beauchamp, M.R. (2003). The relationship between task cohesion and competitive state anxiety. Journal of Sport and Exercise Psychology, 25, 66-76.

Feltz, D., Short, S., \& Sullivan, P. (2007). Self-efficacy in sport: Research and strategies for working with athletes, teams, and coaches. Champaign IL: Human Kinetics Publishers.

Filho, E., Dobersek, U., Gershgoren, L., Becker, B., \& Tenenbaum, G. (2014). The cohesion-performance relationship in sport: A 10-year retrospective meta-analysis. Sport Sciences for Health, 10, 165-177.

Fry, L.W., Kerr, S., \& Lee, C. (1986). Effects of different leader behaviors under different levels of task interdependence. Human Relations, 39, 1067-1082.

Gledhill, A. (2007). BTEC national sport and exercise sciences. Oxford: Heinemann. 
Haddera, T.A. (2015). Assessing the relationships between competitive trait anxiety, self-efficacy and task cohesion in male and female university team sports. CLEAR-International Journal of Research in Management, Sciences \& Technology, 5(10), 1-11.

Hassell, K., Sabiston, C.M., \& Bloom, G.A. (2010). Exploring the multiple dimensions of social support among elite female adolescent swimmers. International Journal of Sport Psychology, 41(4), 340-359.

Hraste, M., Bebić, M., \& Rudić, R. (2013). Where is today's water polo heading? An analysis of the stages of development of the game of water polo. Naše more, 60(Suppl. 1-2), 17-22.

Iturbide, L.M., Elosua P., \& Yanes, F. (2010). Medida de la cohesión en equipos deportivos. Adaptación al español del Group Environment Questionnaire (GEQ). Psicothema, 22(3), 482-488.

Keidel, R.W. (1984). Baseball, football, and basketball: Models for business. Organizational Dynamics, 12, 4-18

Keidel, R.W. (2014). Team sports metaphors in perspective. Organizational Dynamics, 43, 294-302.

Marcos, F.L., Miguel, P.S., Oliva, D.S., \& Calvo, T. G. (2010). Interactive effects of team cohesion on perceived efficacy in semi-professional sport. Journal of Sports Science \& Medicine, 9(2), 320-325.

Mullen, B., \& Copper, C. (1994). The relation between group cohesiveness and performance: An integration. Psychological Bulletin, 115(2), 210-227.

Murray, N. (2006). The differential effect of team cohesion and leadership behavior in high school sports. Individual Differences Research, 4(4), 216-225.

Nascimento Junior, J.R.A., Vieira, L.F., Rosado, A.F.B. \& Serpa, S. (2012). Validação do Questionário de Ambiente de Grupo (GEQ) para a língua portuguesa (Validation of the Group Environment Questionnaire (GEQ) for the Portuguese language). Motriz, Revista de Educação Física, 18(4). 770-782. In Portuguese.

Ohlert, J., Kleinknecht, C., \& Kleinert, J. (2015). Group cohesion reworded-Measuring group cohesion perceptions in sport. Sportwissenschaft, 45(3), 116-126.

Pescosolido, A.P., \& Saavedra, R. (2012). Cohesion and sports teams: a review. Small Group Research, 43(6), $744-758$.

Prokešová, E., Musálek, M., \& Chalupová, E. (2012). A comparison of perceived team cohesion in athletes of interactive and coactive sports based on the Group Environment Questionnaire. Acta Universitatis Carolinae Kinanthropologica, 48(2), 138-145.

Pulido, J.J., García-Calvo, T., Leo, F.M., González-Ponce, I., \& Sánchez-Oliva, D. (2015). Adaptation and validation in Spanish of the Group Environment Questionnaire (GEQ) with professional football players. Psicothema, 27(3), 261-268.

Sabin, S.I., \& Marcel, P. (2014). Group cohesion important factor in sport performance. European Scientific Journal, 10(26), 163-174.

Sindik, J., \& Nazor, D. (2011). Differences in conative characteristics and perceived group cohesion of the basketball players playing in different positions in the team. Collegium Antropologicum, 35(3) 895-904.

Sindik, J., \& Vukosav, J. (2011). The differences between top senior basketball players with different situation efficacy in relation to conative characteristics. Facta Universitatis Series Physical Education and Sport, 9(1), 99-112.

Tekleab, A.G., Quigley, N.R., \& Tesluk, P.E. (2009). A longitudinal study of team conflict, conflict management, cohesion, and team effectiveness. Group and Organization Management, 34(2), 170-205.

Widmeyer, W.N., Brawley, L.R., \& Carron, A.V. (1985). The measurement of cohesion in sport teams: The Group Environment Questionnaire. London, Ont.: Sports Dynamics.

Widmeyer, W.N., \&Williams, J.M. (1991). Predicting cohesion in a coacting sport. Small Group Research, 22, 548-570.

\section{PERCEPCIJA KOHEZIJE U INTERAKTIVNIM SPORTSKIM TIMOVIMA}

Cilj ovog istraživanja je bio da se utvrdi percepcija kohezije u visoko međuzavisnim sportskim timovima, da se uporedi kohezija u različitim sportovima, a zatim uporede socijalna kohezija $i$ kohezija zadatka. Ispitanici su bili 205 profesionalnih sportista iz Beograda koji se bave različitim sportovima: fudbalom, košarkom, odbojkom, rukometom i vaterpolom. Za sakupljanje podataka korišćen je GEQ upitnik (The Group Environment Questionnaire). Sve analize su obavljene uz pomoć statističkog softvera SPSS 22. Rezultati su za sve sportove pokazali umereno visok nivo sve četiri dimenzije kohezije: grupna integracija na osnovu zadatka (GI-T), grupna integracija - socijalna dimenzija (GI-S), individualna privrženost grupi na osnovu zadatka (IATG-T) $i$ individualna privrženost grupi - socijalna dimenzija (IATG-S). Ukupno gledajući, percepcija kohezije zadatka je viša nego percepcija socijalne kohezije. Istraživanje je takođe pokazalo da vrsta sporta utiče na nivo kohezije, pri čemu košarkaši imaju najviši nivo percepcije kohezije od svih sportova.

Ključne reči: sportski timovi, interaktivni sportovi, kohezija, GEQ 